\title{
PROCEEDINGS OF THE ENTOMOLOGICAL SOCIETY OF AMERICA.
}

\section{Atlanta Meeting.}

The Eighth Annual Meeting of the Entomological Society of America was called to order by Dr. Philip P. Calvert in the absence of the President, Rev. Charles J. S. Bethune, at 10:00 A. M., Tuesday, December 30th, in the rooms of the Physiological Department of the Atlanta Medical College. In calling the meeting to order Dr. Calvert conveyed to the Society Dr. Bethune's deep regret at being unable to be present and his hearty good wishes for its success. The meetings were all well attended, the number was surprising considering Atlanta's isolation from great educational centers. The following committee, appointed by President Bethune, was named:

Committee to draft resolutions on the death of Dr. Philip Reese Uhler.-Herbert Osborn, J. H. Comstock, and Philip. P. Calvert.

The chair was directed by motion to appoint the following committees: Committee on Resolutions; Committee on Nominations; Auditing Committee.

The following papers were then read, but through the action of the Executive Committee that all abstracts should be omitted from the proceedings, only titles are given:-

J. T. Lloyd, Cornell University--The structure of the hind intestine of Corydalis.

Paul S. Welch, Kansas Agricultural College--Observations on the habits and life-history of Hydomyza confluens Loew. Read by title.

Stanley B. Fracker, University of Illinois-New characters in the classification of microlepidopterous larvæ.

Cornelia F. Kephart, Cornell University-The poison glands of Euproctis chrysorrhoea Linn. Presented by W. A. Riley.

N. L. Partridge, University of Illinois-The tracheation of the anal area of the wings of the Lepidoptera and the homology of the veins. Read by title.

Herbert Osborn, Ohio State University-The box-elder bug in Ohio. 
V. E. Shelford, University of Chicago-The elytral tracheation of the subfamilies and genera of Cicindelidæ.

Edna Mosher, University of Illinois-Some interesting structures in the pupæ of Lepidoptera.

W. A. Riley, Cornell University-Some sources of error in the interpretation of insect tissue.

J. S. Houser, Ohio Agricultural Experiment StationConwentzia hageni Banks, life-history notes and variations in wing venation.

Alvah Peterson, University of Illinois-Notes on the headstructures of Thysanoptera. Read by title.

Philip P. Calvert, University of Pennsylvania-The desirability of a biographical dictionary of entomologists.

The President announced the following Committees:-

Committee on Resolutions-F. L. Washburn, Henry Skinner, and J. G. Sanders.

Committee on Nominations-W. A. Riley, P. J. Parrott, and G. M. Bentley.

Auditing Committee-T. J. Headlee, H. T. Fernald, and R. H. Pettit.

The Society then adjourned to meet at 2:00 P. M. The afternoon was devoted to a joint meeting of Section $F$ of the American Association for the Advancement of Science and of the Entomological Society of America at which the following papers were presented:-

L. O. Howard, United States Entomologist-Note on the present status of the Gipsy Moth parasites in New England.

E. L. Worsham, State Entomologist of Georgia-Some notes regarding the natural history of the mole cricket.

H. T. Fernald, Massachusetts Agricultural College-Notes on some old European collections.

P. J. Parrott, W. O. Gloyer and B. B. Fulton, New York Agricultural Experiment Station-Studies on the Snowy Treecricket, Oecanthus niveus, with reference to apple bark diseases. Presented by P. J. Parrott.

J. Chester Bradley, Cornell University-Collecting insects in the Okefenoke swamp. Presented by J. G. Needham.

Herbert Osborn, Ohio State University-Studies on the geographical distribution of leaf-hoppers, especially of Maine.

Philip P. Calvert, University of Pennsylvania-The fauna of the epiphytic bromeliads in Costa Rica. 
The Society adjourned at 4:45 P. M., to meet Wednesday, December 31st, at 9:30 A. M.

The annual business meeting of the Society was held upon reconvening and the following reports were presented:-

The committee appointed to draft resolutions on the death of Dr. Philip Reese Uhler presented its report. It was ordered accepted and printed.

The Secretary presented the following report for the Executive Committee, which met at the Hotel Ansley, Tuesday evening. Dr. W. M. Wheeler and Dr. Henry Skinner were named as additional members of the committee. Dr. Skinner sat with the committee.

REPORT OF THE EXECUTIVE COMMITTEE.

The following matters wcre considered in the interim since the last Annual Mecting:- -

The appointment of Dr. E. P. Felt to give the Annual Public Arddress at the Atlanta meeting.

A request from the Secretary that the President be given permission to call for the election of a sufficient number of persons to make a quorum of the Executive Committee at the Atlanta meeting in case there were not four members in attendance.

Mr. Nathan Banks presented a request from the International Committee on Nomenclature of the Second International Congress of Entomology, that this society should name two members to serve on the American National Committee. President Bethune named as representatives, Dr. E. P. Felt and Dr. H. T. Fernald.

Mr. A. W. Baker, Secretary of the Entomological Society of Ontario, presented a request that the Entomological Society of America should send a delegate to its Jubilee meeting, the fiftieth annual meeting, to be held at the Ontario Agricultural College, Guelph, Wednesday, Thursday, and Friday, August 27 to 29. The President named the Secretary as the representative of the Society. Your Secretary had the pleasure of attending these meetings. He had the most delightful time, intellectually and socially, of any scientific meeting that he has attended. There were delegates present from England, Scotland, United States, and Canada.

The following new mombers were elected June 1, 1913:

W. C. Allec.

Frank M. Gibson.
David Gunn.

H. A. Horton.

The following members have died during the year:

D. F. Berrenger.

A. G. Hammar.

Charles W. Hooker.

J. M. Shaffer.

P. R. Uhler. 
The following resignations were presented and accepted:
Otto Bucholz.
Fred Johnson.
P. E. Smith.
C. A. Shull.
R. I. Smith.
Anna C. Stryke.

\section{A. G. Vestal.}

The names of thirteen members were dropped from the rolls for non-payment of dues.

The following new members were elected by the Executive Committee at its meeting last evening:-
L. C. Barber.
W. M. Mann.
G. T. Bethune-Baker.
S. W. Bilsing.
M. W. Blackman.
Josef Bruner.
R. E. Campbell.
Leroy Child.
E. S. Cogan.
W. M. Davidson.
G. A. Dean.
H. F. Dietz.
W. D. Edmonston.
W. O. Ellis.
J. B. Gill.
J. E. Graf.
T. E. Holloway.
J. R. Horton.
E. A. McGregor.
Ximena McGlashan.
J. D. Mitchell.
L. J. Nickels.
F. B. Paddock.
Phil. Rau.
E. A. Richmond.
L. P. Rockwood.
James Sinclair.
M. P. Somes.
Dayton Stoner.
D. T. Stevens.
T. J. Talbert.
J. D. Tothill.
C. T. Vorhies.
H. L. Johnson.
Cornelia F. Kephart.
Otis Wade.
R. J. Kewley.
F. H. Lathrop.
J. R. Watron.
H. B. Weiss.
G. M. Wendelken.
Philip Luginbill.
F. X. Williams.
F. L. McDonough.
T. S. Wilson.
R. S. McDougall.
H. P. Wood.
J. R. Malloch.
W. C. Woods.
M. A. Yothers.

The total membership of the Society as reported at the Seventh Annual meeting was 410 , deducting the names of the persons who have died during the year, resigned, or dropped by the Secretary and adding the names of the new members elected in June and at this meeting, the membership is now 439 .

The Secretary was instructed to prepare a small booklet describing the origin of the Society and its aims, as an aid in further extending the membership.

The first suggestion of a national entomological society was presented at the last Philadelphia meeting in 1904, of the American Association for the Advancement of Science. Dr. Henry Skinner was asked by the Executive Committee to prepare a history of the Entomological Society of America to be read at the Eighth Annual Meeting. 
TREASURER'S REPORT.

RECEIPTS.

Cash on deposit in the First National Bank of Champaign, Illinois,

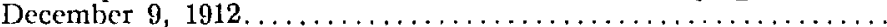

Life Membership Fees deposited with the Cleveland Trust Company,

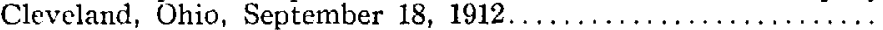

Life Membership Fee of $W$. T. M. Forbes deposited with the Cleveland

Trust Company, of Cleveland, Ohio, September 18, 1913.......

Interest on Fees of Life Members, July 1, 1913................

Cash received from Herbert Osborn, Managing Editor of the Annals...

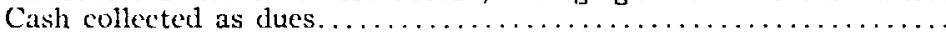

$\$ 40.87$

100.00

50.00

Bills paid:

BALANCE.

Annals and separates for December, $1912 \ldots \ldots \ldots \ldots \ldots \$ \$ 377.47$

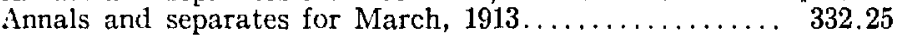

Engraving bills paid by the Treasurer.............. 66.09

Stamps and Stamped envelopes.................. 27.62

Printing for the Secretary-Treasurer's office.......... 28.03

Stenographer.......................... 20.25

One-half guarantec on Cleveland smoker............ 3.67

Check refused by bank............................. 2.00

Life Membership Fees deposited with the Cleveland Trust Company,

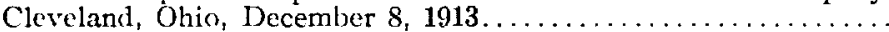
Interest on Fees of Life Members deposited with Cleveland Trust Company, Cleveland, Ohio, December 8, 1913..............

Cash on deposit in the First National Bank of Champaign, Illinois, December 8, 1913

$\$ 857.38$

Dr. C. Gordon Hewitt, Provincial Entomologist of Canada and Dr. William Bames, Lepidopterist of Decatur, Illinois, were elected Fellows of the Society.

It was voted, that in the future no abstracts of the papers presented at the Annual Meeting should be included in the printed proceedings of the meeting.

The following amendment to Article IV, Section 2 of the Constitution was recommended, which reads:

Article IV, Section 2. The business of the Society not otherwise provided for shall be in the hands of an Executive Committee, consisting of the officers named in Scction 1, and of six additional members; five of whom shall be elected from the Fellows by the Society, and the sixth shall be $e x$ officio the Managing Editor. Four members of the Committec shall constitute a quorum.

To be amended to read:

Article IV, Section 2. Executive Committec.-The business of the Society not otherwise provided for shall be in the hands of an Executive Committee, consisting of the officers named in Section 1, and of six additional members, five of whom shall be elected from the Fellows by the Society, and the sixth shall be ex officio the Managing Editor. 
There shall be a meeting of the Executive Committee at each Annual Meeting. Four members shall constitute a quorum and in the case of the non-attendance of this number at any Annual Meeting, the Society shall elect a sufficient number from among the Fellows in attendance to complete the quorum.

On motion the report of the Executive Committee was adopted.

REPORT OF THE MANAGING EDITOR OF THE ANNALS.

The Editor begs leave to report for the past year the following items:

\section{RECEIPTS.}

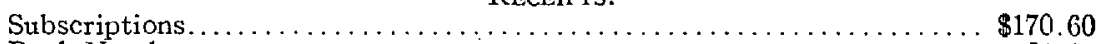

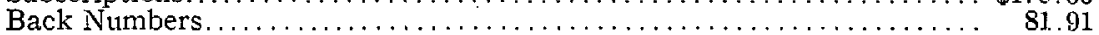

Authors Reprints.................................... 70.00

ExPENDITURES.

$\$ 323.11$

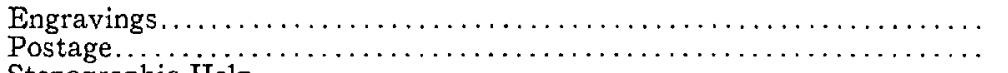

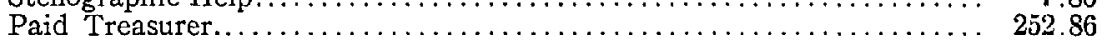

$\$ 323.11$

The volume for the year, which includes about five hundred pages and fifty-nine plates, will I believe maintain the quality of preceding volumes and it has been necessary to postpone or refuse other papers of excellent quality because of the lack of funds for further publication. It is hoped that the income for the coming year will permit the handling of a number of these papers but the Editor believes that the amount printed should be kept within the margin of receipts and if possible no deficit be created. The sale of a few sets of back volumes would assist much in the publication of additional matter and any assistance in placing such sets will be very much appreciated.

The Editor desires to express his appreciation of the aid rendered by the members of the Editorial Board, and to the Secretary for his untiring efforts in attending to the details of the business falling to his office.

Respectfully submitted,

Herbert OSBORN, Managing Editor.

REPORT OF THE AUDITING COMMITTEE.

Your Auditing Committee presents herewith its report. We have examined the books of the Treasurer for the year ending December 8 , 1913 , and find them to be correct. We have also examined the accounts of the Managing Editor of the Annals and find them to be correct.

$$
\begin{array}{ll}
\text { Signed, Thomas J. Headlee; } & \text { H. T. Fernald, } \\
& \text { R. H. Pettit. }
\end{array}
$$


REPORT OF THE COMMITTEE ON NOMINATIONS.

Your committee begs leave to report the following names as nomines for the respective offices for 1914:-

OFFICERS.

President: Philip P. Calvert, University of Pennsylvania, Philadelphia, $\mathrm{Pa}$.

First Vice-President: James G. Needham, Corncll University, Ithaca, N. Y.

Sccond Vice-President: C. Gordon Hewitt, Provincial Entomologist, Ottawa, Camada.

Secretary-Treasurer: Alex. D. MacGillivray, University of Illinois, Urhana, Ill.

ADDITIONAL MEMBERS OF EXECUTIVE COMMITTEE.

Herbert Oshorn, Ohio State University, Columbus, Ohio, ex officio.

William M. Whecler, Harvard University, Cambridge, Mass.

Vernon L. Kollogg, Leland Stanford Jr., University, Stanford University, Cal.

Nathan Banks, United States National Muscum, Washington, D.C.

E. P. Felt, State Entomologist, Albany, N. Y.

J. M. Aldrich, United States Burcau of Entomology, Lafayettc, Ind. MIMBER OF COMMITTEE ON NOMENCLATURF.

T. I. A. Cockerell, University of Colorado, Boulder, Colorado.

$$
\begin{array}{ll}
\text { Signed, } & \text { W. A. Ruley, } \\
& \text { P. J. Parrotr, } \\
\text { G. M. Bentley. }
\end{array}
$$

On motion, the Secretary was instructed to cast a ballot for the officers named and they were declared elected.

REPORT OF THE COMMITTEE ON RESOLUTIONS.

The Committee on Resolutions beg lcave to submit the following:-

Resolved, That the Entomological Socicty of America hercby express their appreciation of the various courtesies extended to them at this meeting by the city of Atlanta, by Governor and Mrs. Slaton, by the University and Capital City clubs, by the Atlanta Medical College, and by the local Press.

Resolved, That its thanks are also due the Atlanta Chamber of Commerce for its hearty co-operation with the University Club and the Atlanta Convention Bureau through whose efforts the meeting at Atlanta was made possible; and further

Resolved. That our thanks are especially due and are hereby extended to the local Executive Committee and Mr. E. L. Worsham for their painstiking and effective efforts in behalf of the convention.

$$
\begin{array}{ll}
\text { Signed, } & \text { F. L. Washburn, } \\
& \text { Henry Skinner, } \\
& \text { J. G. Sanders. }
\end{array}
$$


The Committee on Nomenclature presented an informal report which was ordered accepted.

\section{REPORT OF THE COMMITTEE ON ENTOMOLOGICAL TYPES.}

One of us (Cockerell) examined the collections of the U. S. National Museum and the Carnegie Museum during the year. The types, so far as seen, were found in excellent condition, but not all in systematic order or available for study and comparison without some searching. We know of no museum in which the entomological staff is really adequate. At the Carnegie Museum one is amazed at the richness and value of the collections, including materials which have been described in many important memoirs, and enormous numbers of specimens not yet worked over, but evidently including much of interest. The entomological curator has succeeded in keeping everything in good condition, but it would take a considerable staff of workers to put the collections all in order and keep the accessions worked up. At the U. S. National Museum one finds a large staff of well-known entomologists, many of whom work over time and on holidays in the effort to keep the collections in order and work up the accessions. However, the appearance of an adequate entomological staff is illusory, since nearly all of the men belong to the Bureau of Entomology of the Department of Agriculture, and have to give their attention to economic problems and routine work of various kinds. Judging by the large amount of published work issued from the Museum, one might suppose the number of workers to be sufficient, but this idea is soon dispelled on examining the very large and important collections remaining unstudied and noting the continued stream of accessions. The scientific staff of the National Museum is inadequate in almost all departments, but especially in Entomology, a subject which covers a much greater and more important field than the public imagines. The type problem becomes part of the general problem of securing adcquate and competent curatorial assistance; not only for the proper care and availability of the types already owned by the Museum, but also and especially in regard to obtaining other types. The study and description of the new species now in the Museum would add thousands of types to the collection; while many private workers would give or leave their types to the institution, were entomology treated by Congress and the authorities as it deserves.

We think, therefore, that all entomologists should make a point of urging, whenever possible, the claims of their science to a larger share of support in important Museums. In doing this, they may properly point out the astonishing revelations of recent years in regard to the importance of various insects to man, showing that a knowledge of entomology is of prime importance for the progress of civilization. They may also point out that in the case of large public museums, all the major expenses have been met, and it is only necessary to add a comparatively small amount to greatly increase the scientific output. 
Several workers in the National Museum recently agreed with the suggestion that $5 \%$ of the total expenditure on the Museum, added to the cost of maintaining the scientific departments, would double the scientific out put.

Signed,

T. D. A. Cockereli,

L. O. HOWARD,

HENRy SKinner.

On motion, the report was ordered accepted and printed and the Committee continued for another year.

REPORT OF THE SPECIAL COMMITTEE ON HOLDING A SUMMER MEETING ON THE PACIFIC COAST IN 1915.

Your committee desires to report that there seems to be a strong sentiment in favor of holding a summer meeting on the Pacific coast in 1015 .

It finds the officers of the Panama-Pacific International Exposition willing to co-operate in every reasonable manner, and it is informed that the meeting can be held on the exposition grounds or at either Stanford University or at the University of California. One member of the Committee suggests the desirabliity of a group of entomologists traveling together and arranging to have a field meeting at some Rocky Mountain point. There would probably be no difficulty in arranging for the necessary stop over privileges.

The western entomologists will be enthusjastic supporters of such a gathering and it should be attended by a number of eastern men. We feel it highly desirable to have such a meeting and therefore recommend that arrangements be consumated. We respectfully suggest including in the nominations for 1915 , at least one vice-president who would be in position to serve as chairman of the meeting in case a president was unable to attend.

Signed, E. P. Frit,

V. L. KeLLOGG,

A. J. Cook.

W. M. WhEELER,

T. D. A. Cockerell,

On motion, the report was ordered accepted and printed and the committee was ordered continued as a Committee on Arrangements with the addition of Dr. E. C. Van Dyke of the University of California.

The following amendments to the Constitution submitted at the Cleveland meeting of the Executive Committee were read:-

Article IV, Section 3. The President shall represent the Society upon the Council of the American Association for the Advancement of Science until such time as the Society shall be qualified for representation by two councilors, in which case the second councillor shall be elected from the Fellows by the Executive Committee. 
To be amended to read as follows:

Article IV, Section 3. Councillors to the American Association. The President and the preceding Past-President shall represent the Society upon the Council of the American Association for the Advancement of Science. In case of the death or resignation of either or both councillors, the vacancy shall be filled by the Executive Committee.

Article V, Section 3. Election of Officers. All officers shall be elected by ballot at the Annual Meeting for the term of one year and shall be eligible for re-election. The term of their office shall commence with the first of June following their election.

To be amended to read as follows.

Article V, Section 3. Election of Officers. All officers shall be elected by ballot at the Annual Meeting for the term of one year and shall be eligible for reelection.

On motion, the amendments were adopted.

The Executive Committee at the Cleveland meeting submitted the following addition to the Constitution:

ARTICLE VII.

Section 1. Publication.-The official publication of the Society shall be known as the Annals of the Entomological Society of America. Each volume shall consist of four fascicles and the first fascicle of each volume shall contain the proceedings of the Annual Mecting.

Section 2. Editorial Board.-The publication shall be under the charge of an Editorial Board consisting of ten members, one of whom shall be the Managing Editor. The Managing Editor and his associates shall be responsible for the selection of the material to be published.

Section 3. Election of Editorial Board.-The members of the Editorial Board shall be elected by the Executive Committee. Each member of this board, excepting the Managing Editor, shall serve for three years or until his successor has been elected, three members retiring annually.

SeCtIon 4. Report Managing Editor.-The Managing Editor shall present a report at each Annual Meeting to the Executive Committee and the accounts of his office shall be reported upon by the Auditing Committee.

On motion, this additional article to the Constitution was adopted.

-Mr. H. H. Lyman read a letter from President Bethune expressing his regret at being unable to be present at the meeting. 
On motion, the Secretary was instructed to send a Night Letter to President C. J. S. Bethune, extending greetings from the Society, their pleasure on the recovery of his sight, and their regret at his inability to attend the meetings.

The following communication submitted to the Secretary by $\mathrm{Mr}$. Nathan Banks was read:-

Inasmuch as there is no independant society in this country able to publish large works on Entomology, and since there are even now manuscripts awaiting printing, and with time there will be more, I suggrest that the Entomological Society of America found such a society. This Society to be known as "The Thomas Say Socicty." Its object to publish catalocrues, revisions, and monographs of North American insects. That it be authorized to solicit and collect money for a permanent fund, the interest on which shall be used for the printing of said works. That the Society shall be controlled by a board of five entomologists, chosen by the Executive Committee of the Entomological Society of America. Each member to serve five years, the first board to have one member for one, two, three, four, and five years, thereafter one selected each year. That all money received for sale of publications be added to the permanent fund. That said board of control shall select whatever officers they deem necessary and have authority for accepting articles for printing and disbursement of funds.

On motion, the President was directed to appoint a committee of three to consider ways and means for the establishment of such a society. The President appointed the following committee:-Nathan Banks, Chairman, H. H. Lyman, and Morgan Hebard.

The following papers were then read:--

James Zetek, Panama Canal Zone-The dispersal of Musca domestica.

William Moore, University of Minnesota-A comparison of the enemies of Toxoptera graminum in South Africa and the United States. Presented by F. L. Washburn.

Robert Matheson, Cornell University-Life-history notes on Psephenus lecontei and Hydroporus septentrionalis. Read by title.

V. E. Shelford, University of Chicago-The sequence of color changes during ontogeny in Cicindela.

R. W. Leiby, Cornell University-Notes on the external anatomy of some Pentatomidæ.

L. S. Barber, Florida State College for Women-The biology of Gelechia gallcesolidaginis with some reference to some of its parasites. 
A. F. Conradi, Clemson College-A little known wireworm, Horistonotus uhleri.

Leonard Haseman, University of Missouri-The life-history of a species of Psychodiæ. Read by title.

A. D. MacGillivray, University of Illinois-The Structure of the thorax in generalized insects.

James Zetek, Panama Canal Zone-Behavior of Anopheles tarsimaculata Goldi. Read by title.

J. T. Lloyd, Cornell University-Life-history of Elophila magnificalis, an aquatic lepidopteron. Read by title.

The following exhibits were shown:-

J. S. Houser, Ohio Agricultural Experiment StationConwentzia hageni Banks, a coniopterygid.

E. L. Worsham and J. Chester Bradley, Office State Entomologist of Georgia-Collections of Coleoptera and Odonata from Georgia belonging to Georgia State Board of Entomology.

J. Chester Bradley, Cornell University-Photographs of the Okefenoke swamp.

S. B. Fracker, University of Illinois-Setæ of microlepidopterous larvæ.

James Zetek, Panama Canal Zone-Blue-print upon which was shown the more important data obtained in the study of the behavior of Anopheles tarsimaculata Goldi.

The Annual Public Address of the Society was given on Wednesday evening, December 31st, at the Atlanta Medical College by Dr. Ephraim Porter Felt, State Entomologist of New York, on the Subject of Gall Insects.

A smoker for the entomologists and zoologists in attendance at the meetings was held at the University Club on Thursday evening January 1st, Mr. E. L. Worsham and the staff of the State Entomologists office acting as hosts.

On motion, the Society adjourned to meet in one year with the American Association for the Advancement of Science, at Philadelphia, Pennsylvania.

Alex. D. MaCGillivray, Secretary. 